2. Gemerov G.G, Tugay D.V. Dependence of additional losses in three-phase power supply systems on reactive power and pulsations of instantaneous active power. Tekhnichna elektrodinamika. 2015. No 4. P. 66-70. (Rus)

3. Willems J. L. Budeanu's reactive power and related concepts revisited. IEEE Transactions on Instrumentation and Measurement. 2011. Vol. 60, no. 4. P.1182-1186. (En)

4. Jeltsema Dimitri. Budeanu's concept of reactive and distortion power revisited. Przeglad Elektrotechniczny. 2015. no. 4/201. Pp. 68-73. (En)

5. IEEE Std 1459-2010 IEEE Standard Definitions for the Measurement of Electric Power Quantities Under Sinusoidal, Nonsinusoidal, Balanced, or Unbalanced Conditions, IEEE, 2010, $50 \mathrm{p}$ (En)

6. Bialobrzheskyi O., Rod'kin D., Gladyr A. Power components of electric energy for technical and commercial electricity metering. Naukovyi Visnyk NHU. 2018. № 2. P. 44-53. (En)

7. Rod'kin D.I. Features of the application of the energy method for the identification of alternating-current motors for pseudo-polyharmonic signals. Electromechanical and energy saving systems. 2009. №. 1. P. 7-20. (Rus)

Надійшла 02.03.2018

Received 02.03.2018

\title{
THE CONCEPT OF LINE AUTOMATION SYSTEM AS A COMPONENT OF SMART NETWORKS OF THE FUTURE
}

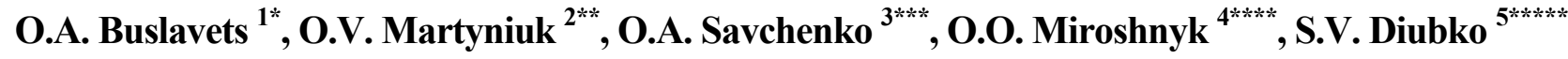

1, 2 - Ministry of Energy and Coal Industry of Ukraine, 30,

Khreshchatyk str., Kyiv, 01601, Ukraine

3-5 - Kharkiv Petro Vasylenko National Technical University of Agriculture,

44 Alchevskyh str., Kharkiv, 61002, Ukraine

e-mail: olga.buslavets@mev.gov.ua, oleksandr.martynuk@mev.gov.ua, savoa@ukr.net, omiroshnyk@ukr.net, stanislavdiubko@gmail.com

The article reflects the authors' vision on the prospects for the development of automation tools used on transmission lines. The authors overviewed briefly the existing elements of transmission lines automation - monitoring systems for various processes, actuating devices. The approach for the integration of individual elements of automation on the PL into a single set of software is offered. It gives grounds for introducing the concept of an automated control system of technological processes of the transmission line (ACSTP PL). The ACSTP PL structural scheme of as a potential component of "smart" networks is reviewed, the group of the monitoring system sensors of the line are described and their general purpose is described. The general requirements for the construction of ACSTP PL, their functional capabilities are formulated. Prospects for the implementation of ACSTP PL and their key technologies are projected. References 10, figures 2, table.

Key words: Smart Grid, power line, line automation system, measurement and monitoring system, control actions, software and hardware complex.

Introduction. Currently, the main trend of electric power systems development in the world is the widespread adoption of Smart Grid technologies. The most complete Smart Grid concept is reflected in the definition of IEEE as a fully integrated electric power system, characterized by selfregulation and self-healing features and managed in real time. Self-regulation and self-healing are the key characteristics of Smart Grid, through which high reliability of power supply with highquality energy is achieved. The basis for realization of these properties is implementation of monitoring of the various processes taking place in the grid, and also control devices that provide network "adaptation" to existing conditions caused by external and internal factors [1].

Smart Grid technologies are relevant for Ukraine, because the electric networks of the country are characterized by a high degree of physical and moral wear of the electric equipment, large losses of electric energy for its transmission, low level of automation, and so on. Thus, by the end of 2017, the share of power lines of distribution networks to be reconstructed, replaced or overhaul exceeded $52 \%$ of their total length. The number of substations that worked out the project resource

\footnotetext{
(C) Buslavets O. A., Martyniuk O.V., Savchenko O.A., Miroshnyk O.O., Diubko S.V., 2018

* ORCID ID: http://orcid.org//0000-0001-6449-7587; ** ORCID ID: http://orcid.org//0000-0002-5278-4789;

*** ORCID ID: http://orcid.org/0000-0002-6401-0852; **** ORCID ID: https://orcid.org/0000-0002-6144-7573;

***** ORCID ID: http://orcid.org/0000-0002-1856-1987
} 
is $48 \%$ of the total. Provision of operators of the distribution systems by modern means of remote high-precision accounting of electric energy is also inadequate. In particular, in networks with voltages above $1 \mathrm{kV}$, about one third of electric meters do not have a remote mode of reading information, and almost half of them have a class of accuracy greater than 0.5 . As a result, it leads to significant losses of electricity in the networks $(11,5 \%$ of the total electricity consumption) and reduces the reliability of electricity supply.

One of the directions of the technical policy provided for by the updated Energy Strategy of Ukraine is the modernization of the network infrastructure using Smart Grid technologies. To this end, the Ministry of Energy and Coal Industry develops the concept of Smart Grid and a phased plan for its implementation by 2035. The concept will provide for the transition from a modern vertically integrated unilateral centralized power supply system to a decentralized intellectual selfregulating power grid. The implementation of Smart Grid should ensure the technical capacity of transmission and distribution system operators to work effectively in a new competitive energy market, taking into account the growth of the share of distributed alternative energy sourses, and will allow achieving the energy supply reliability criteria, $\mathrm{CO}_{2}$ emissions, including reducing SAIDI with a current of more than 600 to less than 150 minutes per consumer per year.

The purpose of the article is to develop the concept of the Line Automation System (LAS) as a component of intelligent electric networks, which involves the use of an integrated hardware and software complex for measurement, monitoring, diagnostics and control of technological processes of transmission or distribution electric power line in real time and aimed at improving reliability and quality of electricity supply, reduction of technological losses of electricity in the line.

The monitoring systems of processes associated with power lines have become a frequent practice recently $[2,3]$. Such systems are often called Real-Time Monitoring Systems (RTMSs). By this system, usually they mean system for determining the permissible capacity of overhead power line (OPL) based on the wire temperature and current monitoring. In this paper the term RTMS refers to the system that can provide real-time monitoring of parameters of different nature characterizing the state of the power line. The list of functional capabilities of the system depends on the specific conditions of the line. For example, climatic conditions, including ice and wind effects, refer to the factors of external influence on OPL. Therefore RTMSs of OPLs, which pass in climate areas with high level of ice loads, should be equipped with software and hardware that allow to monitor the ice and wind conditions and critical parameters of the line in a real-time regime.

Automatic switching devices, such as reclosers, different types of FACTS - OPL pole mounted voltage regulators, reactive power regulators, devices that implement the technology of "smart" wires, etc., belong to control devices which have recently been actively used on power lines. In the future, we can expect increasing of application of such devices on power lines.

RTMS equipment and control devices installed on the power line are the bottom level of an automated system that provides monitoring of various processes associated with the line, transmitting a part of the data to the control center, and control actions issuing, including automatically. Such complex automated systems implemented in substations are known to be called Substation Automation Systems (SASs).

Wide application on power lines of real-time monitoring technologies and various control devices requires their association in one software and hardware complex of integrated automation system (AS) of power line, which will provide new performance capabilities. It affords ground for considering the automation system of power line as a separate component of the electric power system automation. This point of view corresponds to the traditional approach of structural division of electric power systems on such basic elements as power plants, substations, power lines, electricity consumers. For the definitions of automation systems that can be implemented on separate power lines, this paper uses the term Line Automation System, abbreviated as LAS. In [4] the line equipped with automation system, the lower level of which is RTMS and switching devices providing line impedance control, is called Smart Power Line.

As known, the second edition of one of the major standards for information exchange in SASs IEC-61850 is extended to automation systems of other power system objects, as reflected in its title "Communication networks and systems for power utility automation" [5]. According to the IEC approach, SAS is one of the possible subsystems of Power Utility Automation System (PUAS). 


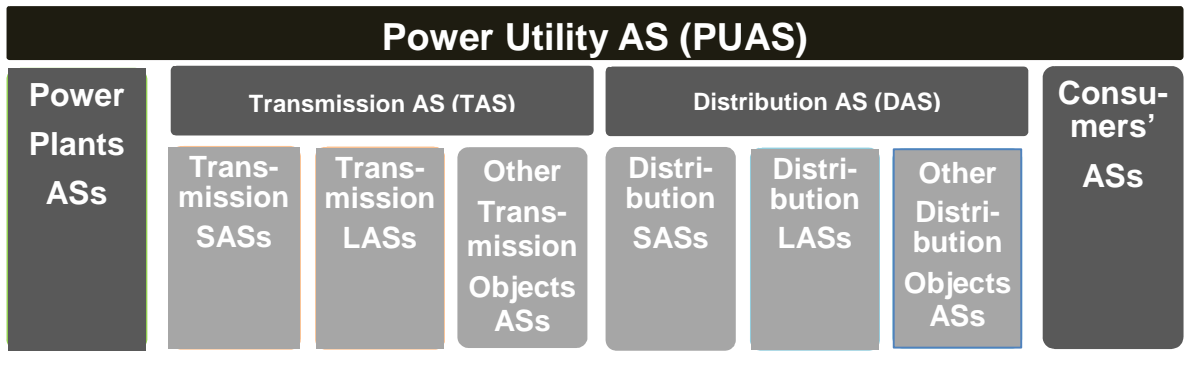

Fig. 1. LAS as a part of PUAS
Thus, LAS can also be considered as one of these subsystems, and at the same time as a separate component of "smart" networks of the future.

As a technical analogy of LAS, automation systems of such elon-

gated engineering objects as gas and oil pipelines can be given.

The types of LAS functions are generally similar to the functions of SAS - these are relay protection, automation functions, monitoring, remote indication and control.

LAS, together with SAS, can be considered as one of the basic components of transmission and distribution automation systems, DASs and TASs respectively. Fig. 1 shows the LAS location in PUAS. Obviously, the concept of LAS can be used in relation to both overhead and cable power lines.

The second section of the paper deals with LAS as one of the elements of Transmission or Distribution SCADA (T(D) SCADA)), it describes a general characteristic of LAS sensors through the example of OPL. The third section of the paper formulates basic requirements for LAS construction, their functionality, and presents the positive results from its implementation. The fourth section is devoted to forecasting the prospects for LAS implementation on power lines. The conclusion is presented in the fifth section of the article.

LAS in T(D) SCADA. The transmission and distribution processes of electric energy are quite complex. They are described with a large number of variables. To control these processes multilevel hierarchical systems which are characterized by the ability of orientation on several targets and can solve conflicts between the elements that make decisions through the intervention of an element of a higher level are used. Taking into account basic properties of Smart Grid, such as self-regulation and self-healing, this system should be at least automated, and eventually most of its functions will be automatic. Fig. 2 shows T(D) SCADA which included LAS.

In general case, elements of OPL and the equipment which is installed on it are LAS monitoring and controlling objects.

The first level of T (D) SCADA is a local level formed with sublevels, that correspond to AS levels of power grid individual objects - power lines, substations and other facilities (for example distribution points). In Fig. 2 the names of AS levels of individual objects of electrical network and data buses correspond to those accepted in the standard IEC-61850 terminology.

At LAS process level various control devices and RTMS sensors are installed. They can be

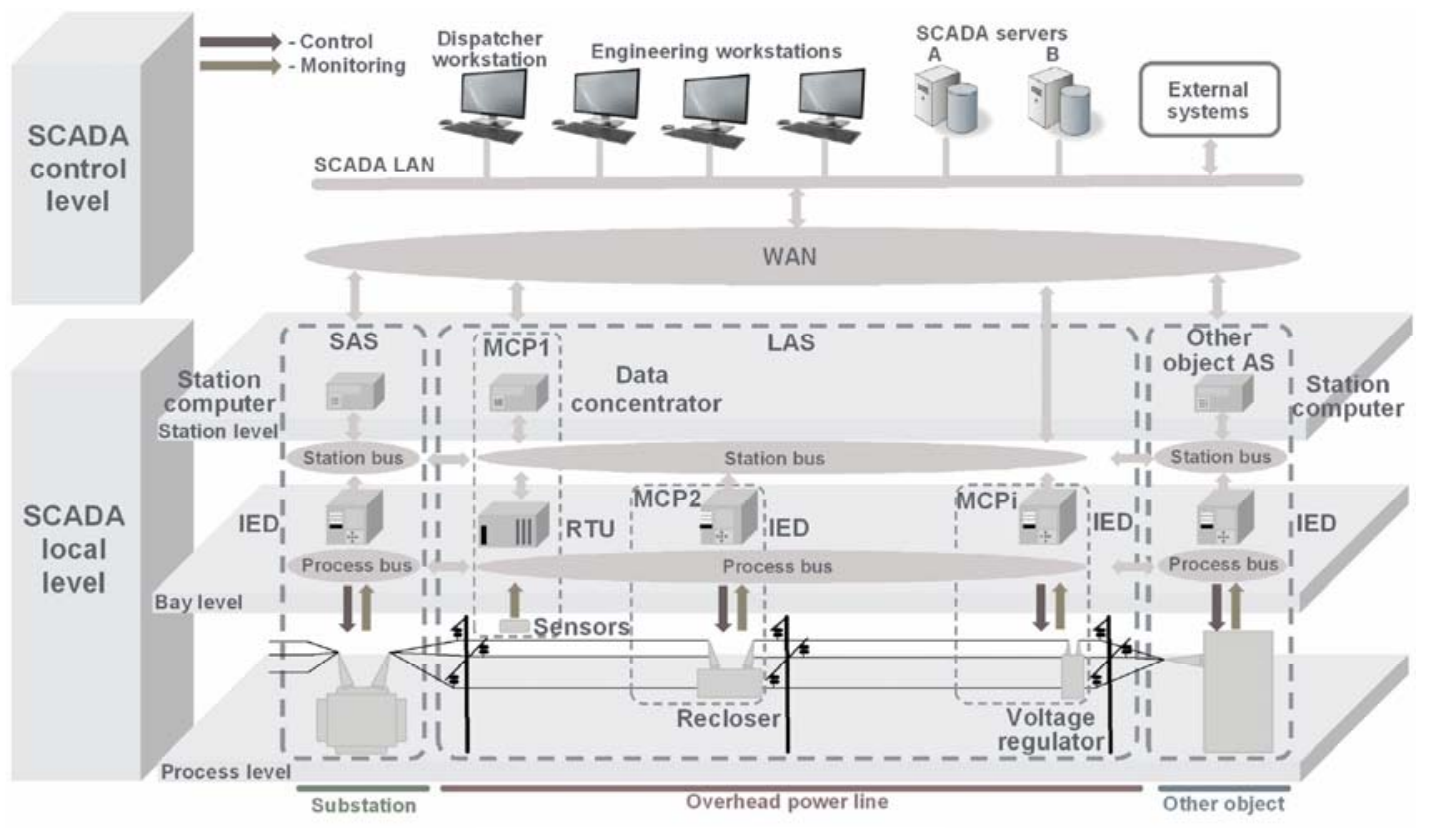

Fig. 2. LAS in T(D) SCADA 
placed in specific monitoring and control points on the line $-M C P 1 \ldots M C P i$ or implemented on a basis of distributed monitoring technology.

RTMS sensors are divided into two groups:

1. Environmental sensors. Since environmental factors (which have natural and artificial character) impact OPL, its monitoring, primarily in order to predict development of the situation and take the necessary measures to prevent failures of the line, is one of the features performed by sensors of this group even today. Some measures can be introduced immediately, automatically, which corresponds to the notion of OPL self-regulation or "adaptation". For example, OPLs which are placed in climatic areas with high level of ice loads in case of prediction of the possibility of ice sediments on wires based on data received from meteorological sensors (factor of natural origin) may automatically transfer into anti-ice regime through some switching. The rest of the measures can be introduced with operational personnel actions, with some time lag. In this case RTMS sensors act as an OPL inspection tool. For example, in [6] there is prediction of the development of technologies which provide the possibility of monitoring on critical approach of vegetation (factor of natural origin), building constructions (artificial factor) to the elements of the line. Here, RTMS sensors act as an inspection tool which lets to introduce the necessary measures in manual mode for preventing OPL failure. On the other hand, OPL impact the environment. Therefore, another feature that can provide sensors of this group is to monitor the impact on the environment. For example, it is possible to monitor the electromagnetic influences near the line, acoustic noise and radio interference generated by corona discharge.

2. OPL elements state sensors. In general, sensors of this group will provide monitoring of electrical, thermal, mechanical and other processes in the elements of the line influencing OPL key features. RTMS equipped with sensors that monitor the current in the phase wires, their temperature, fluctuations intensity, sag, mechanical efforts, are actively used on OPL even today.

The control devices of LAS process level provide "adjustment" of the line to changing conditions. In particular, switching devices, that provide a transfer of the line into preventive mode heating wires in the case of ice forecast [4], can be attributed to such devices.

Microprocessor devices are placed at LAS's bay level; these are programmable logic controllers (PLCs), the input/output modules (RTUs) and other intelligent electronic devices (IEDs) which provide data collection from RTMS sensors and issue of control signals to control devices in particular monitoring and control points $M C P 1 \ldots M C P i$. In terms of information environment architecture in LAS the term "monitoring and control point" is similar to the concept of "bay" in SAS.

The equipment installed at the process and bay levels is associated with common information environment - LAS process bus. Bay level IEDs obtain the information about contact position of switching devices that are installed on the line (reclosers, disconnectors), and about the process parameters at different points of the line through process bus. For example real-time voltage regulation with linear regulators based on the data of the voltage value at various points of the line can be a specific function for distribution lines, the implementation of which is possible through data exchange via LAS process bus.

At LAS's station level data concentrators can be used. The data concentrator provide the information gathering from several points of the monitoring and control, their intermediate archiving and transmitting to higher levels of the hierarchy. In addition, the concentrators allow transmitting the data in the opposite direction. LAS characteristic is the absence of a classical station level, which can be used in SAS and is a collection of workstations (WSs), data collection servers that are PCs. It should be noted that such a situation is typical in SAS, where service personnel is absent.

Bay level IEDs and data concentrators that can be used at the station level, are united through information LAS station bus. The exchange of data between IEDs will be implemented through the station bus. It allows implementing new functions on the line, for example new algorithms of relay protection and automation.

Direct data exchange between LAS and AS of other objects of the electric network can occur through both the process bus and the station bus.

OPL monitoring data, as well as data describing the state of other objects of electric network, by means of communication (WAN) is transferred to the second level of T(D) SCADA - 
control level. The latter is a control point, where a server or servers of data collection, dispatcher's and other WSs are placed. In addition, at this level a part of control signals is generated and transmitted to the control devices which are installed on OPL. Data exchange with external automated systems is organized at the control level.

Requirements for building LAS and its functional capabilities. Based on the analysis of modern automation systems which are used in electric power systems [7] the following basic requirements for LAS were formulated:

1. Modular principle of construction.

2. Openness and possibility of extending of the system based on the international standards relating to hardware and software tools, models of information exchange.

3. The possibility of synergies with other automated systems, e. g. SASs, Other Objects ASs, integrated T(D) SCADA.

4. Optimized level of decentralization, which provide relative functional independence of its elements with simultaneous commercial availability.

Table 1 through the example of an overhead power line shows the list of possible LAS modules, their main functions and some obtained positive results.

LAS division into functional modules is made from the standpoints of system users - staff from different services (operational dispatch service, maintenance personnel, specialists in electricity sales, etc.). Therefore, the table does not reflect the list of automatic functions that do not require human intervention (protection, automatics and so on). Modules division on submodules is possible, each providing a specific functions. At the user level functional modules and submodules of LAS usually should be implemented as specialized software elements of automated control systems (operational and strategic) of electricity transmission (distribution) placed on WSs of different services. Since OPL being objects with elongated nature, software is typically based on GIS-technologies.

Prospects for LASs introduction on power lines. LASs implementation on power lines should take place with considering of all the traditional groups of functions that are specific to AS of other power facilities. First of all, they include relay protection, automation of certain processes (voltage control, reactive power regulating, etc.), real-time monitoring and remote control.

The basis for LASs implementation is organizing an information environment for data exchange between system elements. As known, attractive platform for information exchange in automation systems of electric power objects is standard IEC-61850. As known, this standard was originally developed to provide information exchange between elements in SAS. The standard began gradually to be applied to automation systems of other power facilities, including distributed generation sources, hydroelectric power plants (see for example [8]). There is a draft of a standard adapted for using in Feeder Automation Systems (FASs) [9]. FAS can be considered as a particular case of LAS. Thus, the concept of information exchange adopted in IEC-61850, apparently can be regarded as the basis for implementing data exchange between elements of LAS. Since the notion of a logical node is basic in IEC-61850, one of the tasks to be solved is the decomposition of LAS elements functions into logical nodes.

The questions of ICT use in LASs include such issues as the choice of information network optimal topology, methods to ensure reliable data transfer and physical environment, technologies and communication protocols. Obviously, communication technologies that can become widespread in LASs, are technologies based on using optical fiber, PLC, and also wireless transfer of data.

Another key area for LASs implementation is to develop new concepts of relay protection and automatics algorithms on power lines through the application of high-speed data exchange technologies between IEDs, which are installed at various points of the line, such as technology based on GOOSE-messages defined in IEC-61850. Such decisions have started to be developed and implemented [10].

Technology of OPL distributed monitoring based on fiber optic sensors, which allows watching some line parameters (such as wires or cables temperature) throughout its length is perspective. Optical fiber in some cases can be further used as the physical environment for data transmission. 
LAS functional modules description (through the example of OPL)

\begin{tabular}{|c|c|c|}
\hline & The main functions of the module & Benefits \\
\hline \multirow[t]{2}{*}{1} & \multicolumn{2}{|l|}{ OPL supervisory control module } \\
\hline & $\begin{array}{l}\text { 2. Monitoring and support of decision making in } \\
\text { conditions of high weather loads } \\
\text { 3. Remote control of switching devices, remote } \\
\text { configuration of microprocessor protective relays and } \\
\text { other IEDs } \\
\text { 4. Automatic logging of events associated with OPL }\end{array}$ & $\begin{array}{l}\text { Increasing of OPL capacity, preventing of failures related } \\
\text { with sag violation, exceeding the permissible wires } \\
\text { temperature, improving of power quality, reducing power } \\
\text { losses, reducing time for searching damages on the line, } \\
\text { interruption of power supplying and related with it loses } \\
\text { Improving OPL reliability in conditions of high weather } \\
\text { loads } \\
\text { Reducing the financial costs for salaries of operating } \\
\text { personnel, improving electrical safety, reducing the time } \\
\text { required for control of switching devices installed on the } \\
\text { line and IEDs configuration } \\
\text { Reducing the time spent on record keeping }\end{array}$ \\
\hline \multirow[t]{5}{*}{2} & \multicolumn{2}{|l|}{ Module of OPL maintenance } \\
\hline & $\begin{array}{l}\text { 1. Monitoring, remote diagnosis and OPL's elements } \\
\text { resource assessment (insulators, wires, poles, } \\
\text { connecting clamps, etc.) and the equipment installed } \\
\text { on it (reclosers, linear voltage regulators, etc.) }\end{array}$ & nber of OPL and the equipment \\
\hline & $\begin{array}{l}\text { 2. Remote estimation of weather conditions at the site } \\
\text { of repairs at OPL }\end{array}$ & $\begin{array}{l}\text { Improving the quality of repairs, reducing of power supply } \\
\text { interruptions related to the repairs on OPL }\end{array}$ \\
\hline & $\begin{array}{l}\text { 3. Automated scheduling of OPL repairs (the timing } \\
\text { of repairs, calculation of necessary materials, etc.) }\end{array}$ & Reducing the time spent on planning repairs \\
\hline & $\begin{array}{l}\text { 4. Automated processing of OPL passport, inspection } \\
\text { reports and other documents related to OPL }\end{array}$ & Reducing the time spent on record keeping \\
\hline \multirow[t]{2}{*}{3} & \multicolumn{2}{|l|}{ Electricity sales module } \\
\hline & $\begin{array}{l}\text { 1. Commercial accounting of electricity which is sold } \\
\text { to consumers that are connected to OPL } \\
\text { 2. Power quality and power supply reliability } \\
\text { recording (SAIDI, SAIFI) } \\
\text { 3. Automated billing }\end{array}$ & $\begin{array}{l}\text { Reducing the time required to information gathering about } \\
\text { electricity sales, power quality and power supply } \\
\text { reliability indicators, billing }\end{array}$ \\
\hline \multirow[t]{3}{*}{4} & \multicolumn{2}{|c|}{ Module of strategic management of transmission (distribution) of electric power through OPL } \\
\hline & $\begin{array}{l}\text { 1. Archiving of the data (transients' parameters, } \\
\text { OPL automatic systems, operational control, OPL } \\
\text { maintenance, electricity accounting), analysis and } \\
\text { development of recommendations }\end{array}$ & $\begin{array}{l}\text { Improving the efficiency of automatic systems, } \\
\text { operational control, maintenance, reduction of energy } \\
\text { losses in power line }\end{array}$ \\
\hline & $\begin{array}{l}\text { 2. Gathering statistical data on climate loads on OPL, } \\
\text { their specification }\end{array}$ & Improving the reliability of OPL \\
\hline \multirow[t]{2}{*}{5} & \multicolumn{2}{|l|}{ Module of information security and interoperability } \\
\hline & $\begin{array}{l}\text { 1. Communicating with related automated systems } \\
\text { 2. Protection against unauthorized access }\end{array}$ & $\begin{array}{l}\text { Improving the operational and strategic management of } \\
\text { electricity transmission (distribution) through OPL } \\
\text { Preventing accidents, terrorism }\end{array}$ \\
\hline
\end{tabular}

Conclusion. 1. The prospects for the increasing use of automation on power lines condition the need to unite individual elements of automation associated with a particular line into one integrated line automation system - LAS. This allows us to consider LAS as a separate element of power system automation and at the same time as a component of the future Smart Grid.

2. LASs implementation should be based on principles of modularity, openness and scalability, as well as possibility of their integration into complex transmission (distribution) SCADA.

3. LAS custom's modules and submodules usually should be implemented as specialized software components, and sometimes as separate applications. The main modules of the system include the OPL supervisory control module, module of OPL maintenance, module of strategic management of transmission (distribution) of electric power through OPL, module of information security and interoperability, electricity sales module (if necessary).

4. The key factor of LASs realization is implementation of ICT infrastructure based on highspeed data exchange technology and common standards. This will allow making a significant step in improving the principles of relay protection, automatics, and algorithms of controlled devices which are used on power lines. 
1. Stogniy B.S., Kirilenko O.V., Prakhovnik A.V., Denysiuk S.P. The evolution of smart grids and their prospects in Ukraine. Tehnichna elektrodynamika. 2012. № 5. P. 52-65. (Ukr.)

2. Peabody Evolution of real-time monitoring and its future benefits. Proc. 13th Int. Workshop on Atmospheric Icing on Structures. 2009. P. 156-161.

3. Savchenko O.A., Diubko S.V. Perspective ways of improvement of automated control systems of ice formation on power lines. Problemi energozabezpechennya ta energozberezhennya $v$ APK Ukrayini. Kharkiv: KhNTUA, 2016. Vol. 175. P. 20-23. (Ukr.)

4. Couture P. Smart Power Line and photonic de-icer concepts for transmission-line capacity and reliability improvement. Cold Regions Science and Technology. 2011. Vol. 65, no. 1. P. 13-22.

5. IEC/TR 61850-1 Ed. 2.0 b:2013 Communication networks and systems for power utility automation - Part 1: Introduction and overview, IEC Std. 2013.

6. Future Inspection of Overhead Transmission Lines. Palo Alto: EPRI, Tech. Rep. 1016921, 2008.

7. Padilla E. Substation automation systems: design and implementation. Chichester: Wiley, 2016. 251 p.

8. Kyrylenko O.V., Blinov I.V., Tankevych S.E. Smart Grid and organization of information exchange in electric power systems. Tehnichna elektrodynamika. 2012. № 3. P. 47-48. (Ukr.)

9. Draft IEC TR 61850-90-6 (57/1615/DC): Communication networks and systems for power utility automation Part 90-6: Use of IEC 61850 for Distribution Automation Systems.

10. Feeder Operations in the Blink of an Eye. [Online]. Available: www.tdworld.com/ami/feeder-operations-blink-eye

УДК 621.316

О.А. Буславець ${ }^{1}$, канд. техн. наук, О.В. Мартинюк ${ }^{2}$, канд. техн. наук, О.А. Савченко ${ }^{3}$, канд. техн. наук, О.О. Мірошник ${ }^{4}$ докт. техн. наук, С. В. Дюбко

1, 2 - Міністерство енергетики та вугільної промисловості України,

вул. Б. Хмельницького, 4, Київ, 01601 Україна

3-5 - Харківський національний технічний університет сільського господарства ім. П. Василенка,

вул. Алчевських, 44, Харків, 61002, Україна

КОНЦЕПЦІЯ АВТОМАТИЗОВАНОЇ СИСТЕМИ КЕРУВАННЯ ТЕХНОЛОГІЧНИМИ ПРОЦЕСАМИ ЛІНІЇ ЕЛЕКТРОПЕРЕДАЧІ ЯК СКЛАДОВОЇ «РОЗУМНИХ» МЕРЕЖ МАЙБУТНЬОГО

У статті відображено бачення авторів перспектив розвитку засобів автоматизачії, які використовуються на лініях електропередачі. Проведено короткий огляд існуючих елементів автоматизацї ліній електропередачі - систем моніторингу різноманітних процесів, виконавчих пристроїв. Запропоновано підхід, щзо передбачає інтеграцію окремих елементів автоматизації на ЛЕП в єдиний комплекс програмно-технічних засобів, щзо дає підстави для введення поняття автоматизованої системи керування технологічними прочесами лінї електропередачі (АСКТП ЛЕП). Розглянуто структурну схему АСКТП ЛЕП як потениійної складової «розумних» мереж, охарактеризовано групи давачів системи моніторингу лінії та описано їх загальне призначення. Сформульовано загальні вимоги до побудови АСКТП ЛЕП, їх функціональних можливостей. Спрогнозовано перспективи впровадження АСКТП ЛЕП та їх ключових технологій. Бібл. 10, рис. 2, таблиця.

Ключові слова: «розумна» мережа, лінія електропередачі, автоматизація ЛЕП, система вимірювання та моніторингу, керуючі впливи, комплекс програмно-технічних засобів.

УДК 621.316

О.А. Буславец ${ }^{1}$, канд. техн. наук, А.В. Мартынюк ${ }^{2}$, канд. техн. наук, А.А. Савченко ${ }^{3}$, канд. техн. наук, А.А. Мирошник ${ }^{4}$, докт. техн. наук, С.В. Дюбко ${ }^{5}$

1,2 - Министерство энергетики и угольной промышленности Украины,

ул. Б. Хмельницького, 4, Киев, 01601 Украина

3-5 - Харьковский национальный технический университет сельского хозяйства им. П. Василенко,

ул. Алчевских, 44, Харьков, 61002, Украина

КОНЦЕПЦИЯ АВТОМАТИЗИРОВАННОЙ СИСТЕМЫ УПРАВЛЕНИЯ ТЕХНОЛОГИЧЕСКИМИ ПРОЦЕССАМИ ЛИНИИ ЭЛЕКТРОПЕРЕДАЧИ КАК СОСТАВЛЯЮЩЕЙ «УМНЫХ» СЕТЕЙ БУДУЩЕГО

В статье отражено видение авторов перспектив развития средств автоматизации, которые используются на линиях электропередачи. Проведен краткий обзор существующчих элементов автоматизации линий электропередачи - систем мониторинга различных проиессов, исполнительных устройств. Предложен подход, предусматривающий интеграцию отдельных элементов автоматизации на ЛЭП в единый комплекс программно-технических средств, что дает основания для введения понятия автоматизированной системы управления технологическими процессами линии электропередачи (АСУТП ЛЭП). Рассмотрена структурная схема АСУТП ЛЭП как потенииальной составляющей «умных» сетей, охарактеризованы группь датчиков системы мониторинга линии и описано их общее назначение. Сформулированы общие требования к построению АСУТП ЛЭП, их функциональных возможностей. Спрогнозированы перспективы внедрения АСУТП ЛЭП и их ключевых технологий. Библ. 10, рис. 2, таблица.

Ключевые слова: «умная» сеть, линия электропередачи, автоматизация ЛЭП, система измерения и мониторинга, управляющие воздействия, аппаратно-программный комплекс. 